\title{
Effect of photoperiod on locomotor activity, growth, feed efficiency and gonadal development of Nile tilapia ${ }^{1}$
}

\section{Galileu Crovatto Veras ${ }^{2}$, Luis David Solis Murgas ${ }^{3}$, Priscila Vieira Rosa ${ }^{2}$, Márcio Gilberto Zangeronimo ${ }^{3}$, Matheus Soares da Silva Ferreira ${ }^{3}$, Jonathan Antonio Solis-De Leon ${ }^{3}$}

\author{
${ }_{1}^{1}$ Financed by Conselho Nacional de Desenvolvimento Científico e Tecnológico (CNPq). \\ ${ }^{2}$ Departamento de Zootecnia, Universidade Federal de Lavras, Lavras, MG, Brasil. \\ ${ }^{3}$ Departamento de Medicina Veterinária, Universidade Federal de Lavras, Lavras, MG, Brasil.
}

\begin{abstract}
The objective of this study was to evaluate the effect of photoperiod on locomotor activity, growth and gonadal development in Nile tilapia (Oreochromis niloticus) fingerlings. A completely randomised design was used, with five treatments $(0 \mathrm{~L}: 24 \mathrm{D}, 6 \mathrm{~L}: 18 \mathrm{D}, 12 \mathrm{~L}: 12 \mathrm{D}, 18 \mathrm{~L}: 6 \mathrm{D}$ and $24 \mathrm{~L}: 0 \mathrm{D})$ and four replicates, with the aquarium as the experimental unit. One hundred and sixty fingerlings of tilapia weighing $3.21 \pm 0.05 \mathrm{~g}$ and measuring $4.35 \pm 0.07 \mathrm{~cm}$ each were distributed among 20 aquaria of $20 \mathrm{~L}$ in a recirculation system with the temperature controlled to $27^{\circ} \mathrm{C}$, with eight fish per aquarium. Feeding was carried out twice daily for 75 days, with extruded feed containing $40 \%$ crude protein. The fingerlings subjected to a photoperiod of 12L:12D as well as those under 18L:6D and 24L:0D showed the greatest locomotor activity, whereas those under 6L:18D and $0 \mathrm{~L}: 24 \mathrm{D}$ showed the lowest activity. Fish subjected to a photoperiod of 18L:6D and 24L:0D showed the highest levels of performance. However, manipulation of the photoperiod did not influence the gonadal development, survival or the appearance of deformities in juvenile Nile tilapia. Under long photoperiods (18L:6D and 24L:0D), fish direct their energy to somatic growth and induce best feed efficiency.
\end{abstract}

Key Words: feed intake, fish, locomotor rhythm, Oreochromis niloticus, performance, sexual maturation

\section{Introduction}

The influence of environmental factors on fish has been well studied, especially those related to effects on reproduction and growth (Boeuf \& Bail, 1999). Among these factors, photoperiod acts as a synchroniser of the endogenous rhythm, influencing locomotor activity, growth, metabolic rate, body pigmentation, sexual maturation and reproduction of teleost fish (Boeuf \& Bail, 1999, Biswas et al., 2002; Biswas \& Takeuchi, 2002; Trippel \& Neil, 2003; El-Sayed \& Kawanna, 2004).

Furthermore, photoperiod is one of the most important factors that affects the fish feeding strategy (ReynalteTataje et al., 2002) and in most species, feeding occurs in a non-random way, following certain standard biorhythms, i.e., the circadian rhythms that are influenced by the photoperiod. Thus, diurnal fish are most active in daylight and less active during the dark, whereas the reverse is true for nocturnal fish (Boeuf \& Bail, 1999).

For some species, long photoperiods might indirectly modify growth by eliciting an increased feed intake, developing muscle mass through increased locomotor activity (Boeuf \& Bail, 1999), enhancing nutrient use efficiency (Biswas et al., 2006) and/or redirecting energy from gonadal development into somatic growth (Boeuf \& Bail, 1999; Ginés et al., 2004; Rad et al., 2006).
However, the effect of photoperiod on somatic growth and sexual maturation has been little studied during the early stages of fish development ( $\operatorname{Rad}$ et al., 2006). To date, long photoperiods have been used to stimulate somatic growth and/or delay sexual maturity in some teleost fish such as Atlantic salmon (Salmo salar), Atlantic halibut (Hippoglossus hippoglossus), sea bream (Saparus aurata), sea bass (Dicentrarchus labrax) and Nile tilapia (Oreochromis niloticus) (Boeuf \& Bail, 1999; Oppedal et al., 1999; Jonassen et al., 2000; Simensen et al., 2000; Kissil, et al., 2001; Randall et al., 2001; Gines et al., 2004; Rad et al., 2006). However, the manipulation of photoperiod does not always cause benefits to fish performance and survival. In the long term, changes in the light regime might lead to negative effects on the metabolism and development of fish, especially when extreme photoperiods are used (24L:0D and 24D:0L), which differs considerably from conditions in the wild (Villamizar et al., 2011). The Nile tilapia (Oreochromis niloticus) is noted for its rapid growth under intensive culture and for being a rustic as well as one of the most cultivated species in the world. Currently, some knowledge is available concerning the effects of photoperiod on the growth, feeding efficiency, locomotor activity and sexual maturation of tilapia. However, some information is contradictory, which limits conclusions. 
The objective of study was to evaluate the locomotor activity, growth and sexual maturation of Nile tilapia subjected to different photoperiods.

\section{Material and Methods}

The experiment was conducted at the Laboratory of Photoperiod Fish of Sector Physiology and Pharmacology of the Veterinary Medicine Department, at Universidade Federal de Lavras, MG, Brazil, over 75 days.

The design utilized was randomised with five treatments, i.e., different photoperiods (0L:24D; 6L:18D; 12L:12D; 18L:6D and 24L:0D) and four replicates, with the aquarium as the experimental unit. One hundred and sixty fingerlings of Nile tilapia with initial weight and length of $3.21 \pm 0.05 \mathrm{~g}$ and $4.35 \pm 0.07 \mathrm{~cm}$, respectively, were distributed randomly at a stocking density of eight fish per aquarium.

The experiment was conducted in twenty $20 \mathrm{~L}$ tanks with a water recirculation system and the temperature was controlled by a thermostat. The daily parameters of water quality measured were: temperature $\left(27.2 \pm 0.99{ }^{\circ} \mathrm{C}\right)$ and dissolved oxygen $(7.35 \pm 0.41 \mathrm{mg} / \mathrm{L})$ using oximeter AT 150 - Alfakit, and $\mathrm{pH}(6.65 \pm 0.05)$ was mseasured using $\mathrm{pH}$ meter AT 315 . The ammonium concentration $(0.12 \mathrm{mg} / \mathrm{L})$ was monitored once a week via a card kit ammonia indotest - Alfakit.

Groups of four aquaria were kept in isolation under a controlled lighting system with individual timers and a $20 \mathrm{~W}$ fluorescent lamp with a constant intensity of $1200 \mathrm{~lx}$ at the water surface. All lamps for the respective photoperiods were lit at $07 \mathrm{~h} 00$, except the lighting programmes in which fish were kept under $24 \mathrm{~h}$ light or dark, where the lamps remained on or off, respectively, throughout the experimental period. According to the methodology of Larson et al. (2004), for illumination of the external environment of the laboratory, a $60 \mathrm{~W}$ red lamp was used during feeding, biometrics and cleaning the aquaria.

The fish were fed twice daily at $09 \mathrm{~h} 00$ and $17 \mathrm{~h} 00$, with a commercial extruded feed containing $400 \mathrm{~g} / \mathrm{kg}$ crude protein and pellets $2 \mathrm{~mm}$ in diameter. Thirty minutes after the feed was supplied, any leftover was removed, frozen and dried at $55^{\circ} \mathrm{C}$ to determine intake. The amount of feed was $5 \%$ body weight during the first 15 days and thereafter, and $3 \%$ of body weight by the end of the experiment. The weight and length were measured every 15 days to correct the feed supply.

To assess the locomotor activity of fish, the aquaria were equipped with photocells (Omron, mod E3S-AD62, Kyoto, Japan), which were fixed and centralized to the aquaria. The photocells were connected to a channel board (USB-1024HLS,
Measurement Computing, Norton, Massachusetts, USA) and connected to a computer. These photocells continuously emitted a beam of infrared light and every interruption caused by a fish was counted and recorded on a data sheet by a specialized computer program (DIO98USB, University of Murcia, Spain) at $10 \mathrm{~min}$ intervals. The locomotor activity data were imported into Microsoft Office Excel ${ }^{\circledR} 2007$ and processed and averaged for each treatment.

At the end of the experiment, the fish were deprived of feed for a period of 24 hours. The animals were then anaesthetised in 2-phenoxyethanol $\left(0.6 \mathrm{~mL} . \mathrm{L}^{-1}\right)$, weighed and measured to determine the following performance variables: weight gain $(\mathrm{WG}, \mathrm{g})=$ final weight - initial weight; gain in length $(\mathrm{GL}, \mathrm{cm})=$ final length - initial length; survival rate $(\mathrm{S}, \%)=$ (number of dead fish/total fish $) \times 100$; specific growth rate $\left(\mathrm{SGR}, \%\right.$.day $\left.{ }^{-1}\right)=[(\ln$ final weight $-\ln$ initial weight) $/ 75$ days $] \times 100$; protein efficiency ratio $(\mathrm{PER})=$ weight gain/protein intake; daily feed intake $\left(\mathrm{FI}\right.$, g.day $\left.^{-1}\right)=$ average feed intake $/ 75$ days; feed conversion ratio $(\mathrm{FCR})=$ average feed intake/weight gain. Lastly, all fish from each photoperiod were euthanised in 2-phenoxyethanol $\left(1.0 \mathrm{~mL} . \mathrm{L}^{-1}\right)$ to measure the weight of the gonads.

The analysis was performed using the statistical program Statistica version 7.0. Data were checked for normality using the Shapiro-Wilk normality test $(\mathrm{P}<0.05)$ and the Cochran homogeneity test $(\mathrm{P}<0.01)$ and subjected to ANOVA. Differences $(\mathrm{P}<0.05)$ between means were compared by the Tukey test at $5 \%$ significance. The locomotor activity showed a normal distribution, but the variance of the data was not homogeneous, even after transformation. However, if the size of each sample (i.e., the number of repetitions) are the same, ANOVA is robust with regard to the homogeneity of variances. The survival rate did not show a normal distribution, even after transformation of the data. Thus, for the analysis of this variable, the Kruskal-Wallis test $(\mathrm{P}<0.05)$ was applied and in the case of significance, the test of Dunn at $5 \%$ significance was used.

\section{Results and Discussion}

The photoperiod did not affect the survival rate of Nile tilapia fingerlings (Table 1).

Similar to the present study, other studies with tilapia (El-Sayed \& Kawanna, 2004) and tambaqui (Colossoma macropomum; Mendonça et al., 2009) have also demonstrated no effect of photoperiod on the survival rate of these fish. Shan et al. (2008) showed a lower survival rate in a $0 \mathrm{~L}: 24 \mathrm{D}$ photoperiod, with $100 \%$ mortality after the seventh day of life, in studies with larvae of miiuy 
Table 1 - Means $( \pm$ SD) for measurements and performance of Nile tilapia fingerlings subjected to different photoperiods

\begin{tabular}{|c|c|c|c|c|c|c|}
\hline \multirow{2}{*}{ Variables } & \multicolumn{6}{|c|}{ Photoperiod } \\
\hline & $0 \mathrm{~L}: 24 \mathrm{D}$ & 6L:18D & 12L:12D & 18L:6D & 24L:0D & P-value \\
\hline Survival (\%) & $87.50 \pm 10.21$ & $84.63 \pm 15.27$ & $93.75 \pm 7.22$ & $100.00 \pm 0.00$ & $96.88 \pm 6.25$ & 0.1391 \\
\hline Feed intake $\left(\right.$ g.day $\left.^{-1}\right)$ & $0.52 \pm 0.02 b$ & $0.60 \pm 0.02 \mathrm{a}$ & $0.61 \pm 0.03 \mathrm{a}$ & $0.59 \pm 0.01 \mathrm{a}$ & $0.59 \pm 0.04 \mathrm{a}$ & 0.000 \\
\hline Feed conversion ratio & $1.23 \pm 0.11 \mathrm{ab}$ & $1.32 \pm 0.06 \mathrm{~b}$ & $1.21 \pm 0.07 \mathrm{ab}$ & $1.12 \pm 0.03 \mathrm{a}$ & $1.13 \pm 0.05 \mathrm{a}$ & 0.000 \\
\hline Protein efficiency ratio & $2.05 \pm 0.17 \mathrm{ab}$ & $1.90 \pm 0.08 \mathrm{~b}$ & $2.08 \pm 0.12 \mathrm{ab}$ & $2.25 \pm 0.07 \mathrm{a}$ & $2.21 \pm 0.09 \mathrm{a}$ & 0.001 \\
\hline Final length $(\mathrm{cm})$ & $9.87 \pm 0.38 \mathrm{~b}$ & $10.24 \pm 0.02 \mathrm{ab}$ & $10.52 \pm 0.39 \mathrm{ab}$ & $10.74 \pm 0.29 \mathrm{a}$ & $10.51 \pm 0.42 \mathrm{ab}$ & 0.019 \\
\hline Length gain $(\mathrm{cm})$ & $5.42 \pm 0.49 \mathrm{~b}$ & $5.95 \pm 0.06 \mathrm{ab}$ & $6.18 \pm 0.46 \mathrm{ab}$ & $6.47 \pm 0.36 \mathrm{a}$ & $6.14 \pm 0.43 \mathrm{ab}$ & 0.023 \\
\hline Final weight $(\mathrm{g})$ & $35.12 \pm 3.05 b$ & $37.54 \pm 0.84 \mathrm{ab}$ & $41.33 \pm 1.87 \mathrm{a}$ & $41.75 \pm 2.80 \mathrm{a}$ & $40.86 \pm 2.78 \mathrm{a}$ & 0.005 \\
\hline Weight gain $(\mathrm{g})$ & $31.84 \pm 3.12 b$ & $34.27 \pm 0.81 \mathrm{ab}$ & $38.16 \pm 1.85 \mathrm{a}$ & $38.52 \pm 2.70 \mathrm{a}$ & $37.70 \pm 2.86 \mathrm{a}$ & 0.005 \\
\hline Specific growth rate $\left(\%\right.$ day $\left.^{-1}\right)$ & $3.03 \pm 0.17 \mathrm{~b}$ & $3.15 \pm 0.05 b$ & $3.32 \pm 0.10 \mathrm{a}$ & $3.31 \pm 0.12 \mathrm{a}$ & $3.31 \pm 0.18 \mathrm{a}$ & 0.030 \\
\hline Gonad weight $(\mathrm{g})$ & $0.15 \pm 0.03$ & $0.16 \pm 0.05$ & $0.15 \pm 0.02$ & $0.15 \pm 0.02$ & $0.16 \pm 0.02$ & 0.902 \\
\hline
\end{tabular}

Means $\pm \mathrm{SD}$ in the same row with different letters are significantly different according to the Tukey test $(\mathrm{P}<0.05)$.

croaker, Miichthys miiuy. According to the authors, this high mortality is attributable to the low ability of these larvae to find food in environments with no light. However, Adewolu et al. (2008) showed that fingerlings of African catfish, Clarias gariepinus, had better survival rates when reared under a photoperiod of 0L:24D. The longer survival in this condition can also be attributed to the feeding habit of this species, which feeds comfortably in the dark (Adewolu et al., 2008), dwelling in general, in river bottoms where the incidence of light is low (Feiden et al., 2006). These differences in the survival of different species can be attributed to the extreme variation in the preferred photoperiod, which is species-specific and depends on the stage of development (Britz \& Pienaar, 1992; Silva-Garcia, 1996; Boeuf \& Bail, 1999; Adewolu et al., 2008).

Increased activity was observed in fish subjected to a photoperiod of $12 \mathrm{~L}: 12 \mathrm{D}$, followed by fish exposed to 24L:0D and 18L:6D photoperiods. These photoperiods, in turn, elicited a higher locomotor activity than 6L:18D and 0L:24D photoperiods, respectively (Figure 1).

Tilapias are generally diurnal in a natural environment and in farming conditions, feeding at different times of the day, depending on species and size (Yousuf Haroon et al., 1998; El-Sayed \& Kawanna, 2004). Red tilapia hybrids $(O$. mossambicus $\times$ O. niloticus and $O$. niloticus $\times$ O. mossambicus) exhibit feeding activity during the day, with peak feeding at dusk (Yousuf Haroon et al., 1998; Zav'yalov \& Lavroviskii, 2001). Moreover, adult Nile tilapia (Oreochromis niloticus) exposed to a photoperiod of 12L:12D have shown higher feed intake and feeding activity during the light period when fed with automatic-demand feeders (Toguyeni et al., 1997; Fortes-Silva et al., 2010). The results of these studies confirm the role of photoperiod on feed intake, showing tilapia feeding behaviour to be predominantly diurnal.

The feed intake of animals was affected by the photoperiod. The lowest intake was observed under a

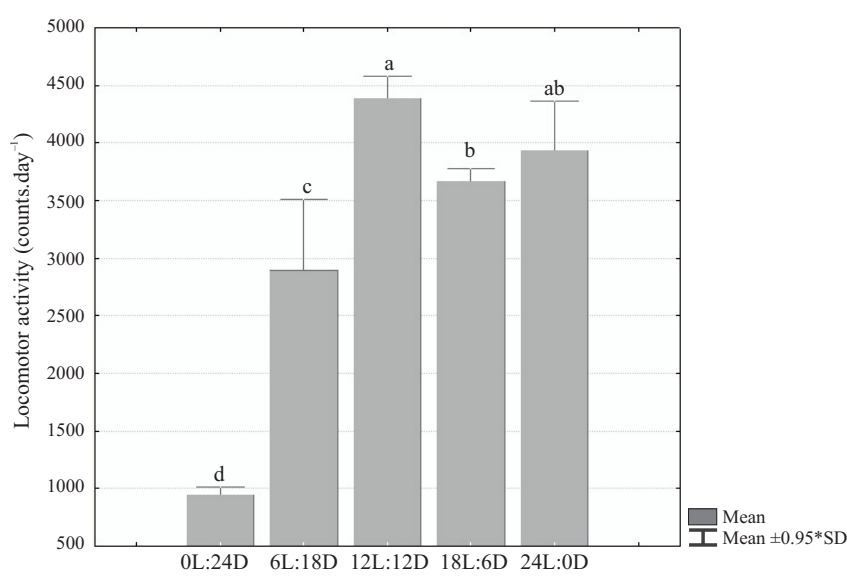

Values followed by different letters are significantly different according to the Tukey test $(\mathrm{P}<0.001)$

The coefficient of variation $(\mathrm{CV})$ of activity within each photoperiod was: $0 \mathrm{~L}: 24 \mathrm{D}$ $(\mathrm{CV}=7.00 \%), 6 \mathrm{~L}: 18 \mathrm{D}(\mathrm{CV}=22.65 \%), 12 \mathrm{~L}: 12 \mathrm{D}(\mathrm{CV}=5.00 \%), 18 \mathrm{~L}: 6 \mathrm{D}(\mathrm{CV}=3.00 \%)$ and $24 \mathrm{~L}: 0 \mathrm{D}(\mathrm{CV}=12.00 \%)$.

Figure 1 - Effect of the photoperiod on locomotor activity of Nile tilapia (mean \pm standard deviation).

0L:24D photoperiod. However, the fingerlings subjected to photoperiods of $6 \mathrm{~L}: 18 \mathrm{D}, 12 \mathrm{~L}: 12 \mathrm{D}, 18 \mathrm{~L}: 6 \mathrm{D}$ and $24 \mathrm{~L}: 0 \mathrm{D}$ showed no difference (Table 1).

The lowest feed intake found in fish under a 0L:24D photoperiod was probably due to the rhythmic behaviour of the species; tilapia in this treatment showed low locomotor activity, demonstrating the low energy of this species in the dark phase. According to Dabrowski (1975), fish that make use of vision to capture food might be harmed when food is distributed in environments where there is low light, or where the light period during the day is short. The increase in feed intake under long photoperiods might be due to the increased activity of fish under these conditions; they have a greater foraging activity when food is provided (Johnson \& Björnsson, 1994; Mccormick et al., 1995; Biswas et al., 2005, Biswas et al., 2006), which then stimulates the production of orexigenic hormones. Furthermore, in 
studies with salmon, growth hormones have been shown to be released under continuous light, which is thought to have a positive effect on appetite, which becomes stronger with longer periods of light exposure (Johnsson \& Björnsson, 1994; McCormick et al., 1995).

Feed conversion and protein efficiency ratio were influenced by the different photoperiods. Fish subjected to $18 \mathrm{~L}: 6 \mathrm{D}$ and $24 \mathrm{~L}: 0 \mathrm{D}$ showed the best conversion rates and the protein efficiency ratio did not differ between them. Moreover, fingerlings exposed to 6L:18D showed the worst conversion value and protein efficiency ratio. Fish subjected to $0 \mathrm{~L}: 24 \mathrm{D}$ and $12 \mathrm{~L}: 12 \mathrm{D}$ showed a similar value of feed conversion and protein efficiency ratios among them and among fingerlings under a photoperiod of $6 \mathrm{~L}: 18 \mathrm{D}$, as well as fish under photoperiods of 18L:6D and 24L:0D (Table 1).

The best feed conversion and protein efficiency ratios found in fish subjected to long photoperiods could be attributed to the time during which the animals were exposed to light after the second feeding. In this case, the fish possibly had the highest appetite, as demonstrated by Biswas et al. $(2005,2006)$. As described in a review by Boeuf \& Bail (1999), Gross et al. (1965) were the first to demonstrate that growth is influenced by photoperiod by not only stimulating consumption, but also by improving the feed conversion ratio. Biswas et al. $(2005,2006)$ showed that long intervals between feeding fish during a long and constant photoperiod might allow for more efficient digestion, which probably improved nutrient retention. The same effect might have occurred in the tilapia fingerlings exposed to $18 \mathrm{~L}: 6 \mathrm{D}$ and $24 \mathrm{~L}: 0 \mathrm{D}$ in this study, since these fish showed better protein efficiency ratios. The long period of light between the first and second feeding (16 h) might mean that these fish have better efficiency of dietary protein use due to improvement in the digestive process.

The final length and gain in length of fish kept under 18L:6D was higher than for those exposed to the other photoperiods. However, the fish under a 0L:24D photoperiod showed the smallest increase in length. The fingerlings under photoperiods of $6 \mathrm{~L}: 18 \mathrm{D}, 12 \mathrm{~L}: 12 \mathrm{D}$ and 24L:0D showed a final length and gain in length similar to those under a 18L:6D photoperiod (Table 1).

The greatest final weight and weight gains were shown by fish under photoperiods of 18L:6D, 24L:6D and 12L:12D, and were not significantly different between treatments. Fish under the 0L:24D treatment had the lowest weight gain and fingerlings in the $6 \mathrm{~L}: 18 \mathrm{D}$ photoperiod showed a final weight and weight gain similar to those kept under 12L:12D, 18L:6D and 24L:0D photoperiods (Table 1).

Fish in the 12L:12D, 18L:6D and 24L:0D treatments had the highest growth rates, which did not differ significantly among these photoperiods. However, fingerlings in the 0L:24D and 6L:18D treatments had the lowest specific growth rates (Table 1).

The growth data obtained in this study corroborate those in a study of post-fry Nile tilapia. El-Sayed \& Kawanna (2004) showed that post-fry subjected to a long photoperiod (18L:6D and 24L:0D) showed the highest specific growth rate and also showed a trend of increased growth of fingerlings of the same species when they were subjected to photoperiods of 18L:6E and 24L:0D. Bezerra et al. (2008) also showed that Nile tilapia subjected to a long photoperiod (16L:8D and 24L:0D) possessed higher growth and survival rates. Rad et al. (2006) demonstrated that Nile tilapia grew best under a photoperiod of $24 \mathrm{~h}$ light when compared with 20L:4D and 18L:6D photoperiods. Long photoperiods also promote higher growth in other species such as juvenile red sea bream (Biswas et al., 2005), striped knifejaw (Oplengnathus fasciatus, Biswas et al., 2008), larvae and juveniles of croaker miiuy (Miichthys miiuy, Shan et al., 2008), fingerlings of Persian sturgeon (Acipenser persicus, Zolfaghari et al., 2011) and tambaqui (Mendonça et al., 2012), among others.

Long photoperiods might indirectly modify fish growth via the development of muscle mass due to increased locomotor activity (Boeuf \& Bail, 1999). In fishes subjected to photoperiods of $12 \mathrm{~L}: 12 \mathrm{D}, 18 \mathrm{~L}: 6 \mathrm{D}$ and $24 \mathrm{~L}: 0 \mathrm{D}$, some energy might be redirected to meet the energy demand due to an increased locomotor rhythm. Increased swimming activity probably stimulated the deposition of amino acids for body protein formation, thus leading to a higher growth of these fish (Biswas et al., 2005). This might be because body proteins are responsible for the majority of growth in terms of weight gain (Biswas et al., 2005). In addition to increased protein deposition, fish exposed to long and continuous photoperiods might still have a low body lipid concentration, indicating that some lipids might have been used to supply the high energy demand of increased activity (Ginés et al., 2004; Biswas et al., 2005).

In some species, the increase in photoperiod and temperature led to rapid increases in GH and IGF-1, which are particularly potent stimulators of muscle growth (Taylor \& Migaud, 2009). According to Taylor et al. (2005), juvenile rainbow trout (Oncorhynchus mykiss) subjected to a long photoperiod (18L:6D) demonstrate a direct stimulation in growth due to increased plasma levels of IGF-1 compared with fish subjected to natural photoperiod or a $6 \mathrm{~L}: 18 \mathrm{D}$ photoperiod.

The manipulation of photoperiod to improve the growth of fish has become increasingly common in the production of several commercial species (Taylor \& Migaud, 2009). 
However, recently, long photoperiods or constant light have been shown to have a negative effect on the early development of some fish species (Villamizar et al., 2011). According to Villamizar et al. (2009), European sea bass larvae developed fins and teeth faster in constant light (24L:0D), than under 0L:24D or 12L:12D; however, their well-being was compromised, as demonstrated by low bladder inflation 17 days after hatching, as well as by the presence of larvae with malformed jaws. A similar result was shown by larvae of Senegal sole, Solea senegalensis, kept in constant light (Blanco-Vives et al., 2010). However, in this study, manipulation of the photoperiod showed no influence on malformation of Nile tilapia.

The manipulation of photoperiod had no influence on the gonadal development of Nile tilapia. This result differs from others, in which the manipulation of photoperiod influenced the gonadsomatic index (GSI) of fishes (Boeuf \& Bail, 1999; Ginés et al., 2003; Ginés et al., 2004; Rad et al., 2006). However, comparisons of the GSI between fishes of statistically different weight do not represent actual gonadal development. For example, fish of different sizes have a similar weight of gonads. Due to weight differences, heavier fish might have a lower GSI than lighter ones, as the GSI is inversely proportional to the final weight; this was the case when the GSI was determined in the present study. The same appeared to occur in a similar study with Nile tilapia subjected to different photoperiods (Rad et al., 2006), where fingerlings under longer photoperiods showed the highest growth and a lower GSI, compared with fish in a natural photoperiod (12L:12D), which showed the lowest growth.

\section{Conclusions}

Long photoperiods (18L:6D and 24L:0D) induce the best growth, feed conversion ratio and protein efficiency ratios in Nile tilapia fingerlings. However, manipulation of the photoperiod does not influence survival, the appearance of body deformations or gonadal development.

\section{References}

ADEWOLU, M.A.; ADENIJI, C.A.; ADEJOBI, A.B. Feed utilization, growth and survival of Clarias gariepinus (Burchell 1822) fingerlings cultured under different photoperiods. Aquaculture, v.283, p.64-67, 2008.

BEZERRA, K.S.; SANTOS, A.J.G.; LEITE, M.R. et al. Crescimento e sobrevivência da tilápia chitralada submetida a diferentes fotoperíodos. Pesquisa Agropecuária Brasileira, v.43, p.737-743, 2008.

BISWAS, A.K.; TAKEUCHI, T. Effects of different photoperiod cycles on metabolic rate and energy loss of both fed and unfed adult tilapia Oreochromis niloticus: part II. Fisheries Science, v.68, p.543-553, 2002
BISWAS, A.K.; ENDO, M.; TAKEUCHI, T. Effect of different photoperiod cycles on metabolic rate and energy loss of both fed and unfed young tilapia Oreochromis niloticus: Part I. Fisheries Science, v.68, p.465-477, 2002.

BISWAS, A.K.; SEOKA, M.; INOUE, Y. et al. Photoperiod influences the growth, food intake, feed efficiency and digestibility of red sea bream (Pagrus major). Aquaculture, v.250, p.666-673, 2005.

BISWAS, A.K.; SEOKA, M.; TANAKA, Y. et al. Effect of photoperiod manipulation on the growth performance and stress response of juvenile red sea bream (Pagrus major). Aquaculture, v.258, p.350-356, 2006.

BISWAS, A.K.; SEOKA, M.; UENO, K. et al. Growth performance and physiological responses in striped knifejaw, Oplegnathus fasciatus, held under different photoperiods. Aquaculture, v.279, p.42-46, 2008.

BLANCO-VIVES, B.; VILLAMIZAR, N.; RAMOS, J. et al. Effect of daily thermo and photo-cycles of different light spectrum on the development of Senegal sole (Solea senegalensis) larvae. Aquaculture, v.306, p.137-145, 2010.

BOEUF, G.; BAIL, P.Y.L. Does light have an influence on fish growth? Aquaculture, v.177, p.129-152, 1999.

BRITZ, P.J.; PIENAAR, A.G. Laboratory experiments on the effect of light and cover on the behaviour and growth of African catfish, Clarias gariepinus (Pisces: Clariidae). Journal of Zoology, v.227, p.43-62, 1992.

DABROWSKI, K. The point of no return in early fish life. An attempt to determine the minimal food requirement. Wiadomosci Ekologiczne, v.21, p.277-293, 1975.

EL-SAYED, A.F.M.; KAWANNA, M. Effects of photoperiod on the performance of farmed Nile tilapia Oreochromis niloticus. I-Growth, feed utilization efficiency and survival of fry and fingerlings. Aquaculture, v.231, p.393-402, 2004.

FEIDEN, A.; HAYASHI, C.; BOSCOLO, W. R. et al. Desenvolvimento de larvas de Steindachneridion sp. em diferentes condições de refúgio e luminosidade. Pesquisa Agropecuária Brasileira, v.41, p.133-137, 2006.

FORTES-SILVA, R.; MARTÍNEZ, F.J.; VILLARROEL, M. et al. Daily feeding patterns and self-selection of dietary oil in Nile tilapia. Aquaculture Research, v.42, p.157-160, 2010.

GINÉS, R.; AFONSO, J.M.; ARGUELLO, A. et al. Growth in adult gilthead sea bream (Sparus aurata L.) as a result of interference in sexual maturation by different photoperiod regimes. Aquaculture Research, v.34, p.73-78, 2003.

GINÉS, R.; AFONSO, J.M.; ARGUELLO, A. et al. The effects of long-day photoperiod on growth, body composition and skin colour in immature gilthead sea bream (Sparus aurata L.). Aquaculture Research, v.35, p.1207-1212, 2004.

GROSS, W.L.; ROELOFS, E.W.; FROMM, P.O. Influence of photoperiod on growth of green sunfish, Lepomis cyanellus. Journal of the Fisheries Research Board of Canada, v.22, p.1379-1386, 1965.

JONASSEN, T.M.; IMSLAND, A.K.; STEFANSSON, S.O. Interaction of temperature and light on growth in Atlantic halibut, Hippoglossus hippoglossus. Aquaculture Research, v.31, p.219-227, 2000.

JOHNSSON, J.I.; BJÖRNSSON, B.T. Growth hormone increases growth rate, appetite and dominance in juvenile rainbow trout, Oncorhyncus mykiss. Animal Behaviour, v.48, p.177-186, 1994.

KISSIL, G.W.; LUPATSH, I.; ELIZUR, A. et al. Long photoperiod delayed spawning and increased somatic growth in gilthead seabream (Sparus aurata). Aquaculture, v.200, p.363-379, 2001.

LARSON, E.T.; WINBERG, S.; MAYER, I. et al. Social stress affects circulating melatonin levels in rainbow trout. General and Comparative Endocrinology, v.136, p.322-327, 2004.

MCCORMICK, S.D.; BJÖRSSON, TH.; SHERIDAN, M. et al. Increased daylength stimulates plasma growth hormone and gill $\mathrm{Na}^{+}, \mathrm{K}^{+}$-ATPase in Atlantic salmon (Salmo salar). Journal of Comparative Physiology B, v.165, p.245-254, 1995. 
MENDONÇA, P.P.; FERREIRA, R.A.; VIDAL JUNIOR, M.V. et al. Influência do fotoperíodo no desenvolvimento de juvenis de tambaqui (Colossoma macropomum). Archivos de Zootecnia, v.58, p.323-331, 2009.

MENDONÇA, P.P.; VIDAL JUNIOR, M.V.; POLESE, M.F. et al. Morphometrical development of tambaqui (Colossoma macropomum, Cuvier, 1818) under different photoperiods. Revista Brasileira de Zootecnia, v.41, p.1337-1341, 2012.

OPPEDAL, F.; TARANGER, G.L.; JUELL, J-E. et al. Growth, osmoregulation and sexual maturation of underyearling Atlantic salmon smolt Salmo salar L. exposed to different intensities of continuous light in sea cages. Aquaculture Research, v.30, p.491-499, 1999.

RAD, F.; BOZAOĞLU, S.; GÖZÜKARA, S.E. et al. Effects of different long-day photoperiods on somatic growth and gonadal development in Nile tilapia (Oreochromis niloticus L.). Aquaculture, v.255, p.292-300, 2006.

RANDALL, C.; NORTH, B.; FUTTER, W. et al. Photoperiod effects on reproduction and growth in rainbow trout. Trout News, v.32, p.403-410, 2001.

REYNALTE-TATAJE, D.; LUZ, R.K.; MEURER, S. et al. Influência do fotoperíodo no crescimento e sobrevivência de pós-larvas de piracanjuba Brycon orbignyanus (Valenciennes, 1849)(Osteichthyes, Characidae). Acta Scientiarum, v.24, p.439-443, 2002.

SHAN, X.; XIAO, Z.; HUANG, W. et al. Effects of photoperiod on growth, mortality and digestive enzymes in miiuy croaker larvae and juveniles. Aquaculture, v.281, p.70-76, 2008.

SILVA-GARCIA, A.J. Growth of juvenile gilthead seabream (Sparus aurata L.) reared under different photoperiod regimes. Israeli Journal of Aquaculture-Bamidgeh, v.48, p.84-93, 1996.

SIMENSEN, L.M.; JONASSEN, T.M.; IMSLAND, A.K. et al. Photoperiod regulation of growth of juvenile Atlantic halibut (Hippoglossus hippoglossus L.). Aquaculture, v.190, p.119-128, 2000.
TAYLOR, J.F.; MIGAUD, H.; PORTER, M.J.R. et al. Photoperiod influences growth rate and plasma insulin-like growth factor-I levels in juvenile rainbow trout, Oncorhynchus mykiss. General and Comparative Endocrinology, v.142, p.169-185, 2005.

TAYLOR, J.; MIGAUD, H. Timing and duration of constant light affects rainbow trout (Oncorhynchus mykiss) growth during autumn-spring grow-out in freshwater. Aquaculture Research, v.40, p.1551-1558, 2009.

TOGUYENI, A.; FAUCONNEAU, B.; BOUJARD, T. et al. Feeding behaviour and food utilisation in tilapia, Oreochromis Niloticus: Effect of sex ratio and relationship with the endocrine status. Physiology \& Behavior, v.62, p.273-279, 1997.

TRIPPEL, E.A.; NEIL, S.R.E. Effects of photoperiod and light intensity on growth and activity of juvenile haddock (Melanogrammus aeglefinus). Aquaculture, v.217, p.633-645, 2003.

VILLAMIZAR, N.; GARCÍA-ALCAZAR, A.; SÁNCHEZVÁZQUEZ, F.J. Effect of light spectrum and photoperiod on the growth, development and survival of European sea bass (Dicentrarchus labrax) larvae. Aquaculture, v.292, p.80-86, 2009.

VILLAMIZAR, N.; BLANCO-VIVES, B.; MIGAUD, H. et al. Effects of light during early larval development of some aquacultured teleosts: A review. Aquaculture, v.315, p.86-94, 2011.

YOUSUF HAROON, A.K.; PITMAN, K.A.; BLOM, G. Diel feeding pattern and ration of two sizes of tilapia Oreochromis spp. in pond and paddy field. Asian Fisheries Society, v.4, p.281-301, 1998.

ZOLFAGHARI, M.; IMANPOUR, M. R.; NAJAFI, E. Effect of photoperiod and feeding frequency on growth in feed utilization of fingerlings Persian sturgeon (Acipenser persiscus). Aquaculture Research, v.42, p.1594-1599, 2011.

ZAV'YALOV, A.P.; LAVROVSKII, V.V. Diurnal rhythms of feeding red tilapia Oreochromis niloticus x O. mossambicus reared in an apparatus with a closed cycle of water supply. Journal of Ichthyology, v.41, p.435-441, 2001. 